Research Article

\title{
Examining the Relationship between Fear of COVID-19 and Spiritual Well-being
}

\author{
Figen Kasapoğlư ${ }^{1}$ \\ Istanbul 29 Mayıs University
}

1 Asst. Prof., Department of Educational Sciences, Istanbul 29 Mayı University, Istanbul, Turkey. E-mail: figenkasapoglu.721@gmail.com.tr

\begin{abstract}
The continuing spread of the COVID-19 (coronavirus) pandemic has psychological effects on many individuals. One of these effects is the fear of COVID-19. In this study, it is aimed to examine the fear of COVID-19 in terms of spiritual well-being. In addition, the fear of COVID-19 was examined within the framework of gender, age range, education, income level, whether there is someone diagnosed with COVID-19 nearby and marital status. The study group of the research consisted of 474 adults (261 females, 213 males) were selected by the convenient sampling method. The research method is the correlational survey model. Data was obtained using the Demographic Information Form, the Spiritual Well-being Scale, and the COVID-19 Fear Scale. Descriptive statistics, t-test for independent groups, ANOVA, Pearson Correlation test and regression analysis were used in the study. Group comparison analysis revealed that women experienced higher levels of fear of the coronavirus. While those with postgraduate education reported significantly lower levels of fear of the coronavirus than those with other education levels. Fear of the coronavirus did not differ according to the age range, income level, and marital status of the participants. According to the results of the correlation analysis, a negative correlation between the fear of coronavirus and spiritual well-being and sub-dimension of spiritual well-being "transcendence" was found; and a positive correlation between the fear of the coranavirus and the sub-dimension of spiritual well-being "anomie" was found. Regression analysis showed that "anomie" positively predicted the fear of coronavirus. The findings of the research were discussed within the scope of the related literature. Keywords:

COVID-19 Fear of COVID-19 Spiritual Well-Being Transcendence Anomie Turkey
\end{abstract}

\section{COVID-19 Korkusu ile Spirituiel İyi Oluş Arasındaki İlişkinin İncelenmesi}

Öz

Dünyada yayılmaya devam eden COVID-19 (Yeni Coranavirüs) pandemisinin birçok birey üzerinde psikolojik etkilerinin olduğu görülmektedir. Bu etkilerden biri de COVID-19 korkusudur. Bu araştırmada COVID-19 korkusunu spiritiuel iyi oluş açısından incelemek amaçlanmıştır. Ayrıca COVID-19 korkusu cinsiyet, yaş aralığı, eğitim, gelir seviyesi, yakınında COVID-19 tanısı alan birinin olup olmadığı ve medeni durum değişkenleri çerçevesinde de incelenmiştir. Araştırmanın çalışma grubu uygun ve kolay ulaşılabilir örnekleme yöntemi ile seçilen 474 (261 kadın, 213 erkek) yetişkin bireyden oluşmuştur. Araştırma yöntem olarak ilişkisel tarama modelidir. Veriler Demografik Bilgi Formu, Spiritüel İyi Oluş Ölçeği ve COVID-19 Korkusu Ölçeği kullanarak elde edilmiştir. Araştırmada tanımlayıcı istatistikler, bağımsız gruplar için $t$ testi, ANOVA, Pearson Korelasyon testi ve regresyon analizi yapılmıştır. Grup karşılaştırma analizleri kadınların daha yüksek koronavirüs korkusu bildirdiklerini ortaya koymuștur. Lisansüstï eğitimli olanlar diğer eğitim düzeylerine sahip olanlara göre anlamlı ölçüde daha düşü̈k koronavirüs korkusu bildirirken, koronavirüs korkusu katılımcıların yaş aralığına, gelir seviyesine, medeni durumuna göre farklılık göstermemiștir. Korelasyon analizi sonuçlarına göre, koranavirüs korkusu ile spirituiel iyi oluş ve spirituiel iyi oluşun alt boyutu "aşkınlık" arasında negatif korelasyon; spirituiel iyi oluşun alt boyutu "anomi" arasında pozitif korelasyon bulunmuştur. Regresyon analizi, "anomi”nin koronavirüs korkusunu pozitif yönde yordadığını göstermiştir. Araştırmanın bulguları ilgili alan yazın çerçevesinde tartışılmıştır. Anahtar Kelimeler:

COVID-19 • COVID-19 Korkusu • Spiritüel İyi Oluş • Aşkınlık • Anomi • Türkiye.

Citation: Kasapoğlu, F. (2020). Examining the relationship between fear of COVID-19 and spiritual well-being. Spiritual Psychology and Counseling, 5, 341-354. https://dx.doi.org/10.37898/spc.2020.5.3.121 
COVID-19, which was detected in China at the end of 2019 was declared as a pandemic by the World Health Organization (WHO) on $11^{\text {th }}$ March, 2020. This pandemic has affected many countries, including Turkey. As of $24^{\text {th }}$ October, 2020, 42.055.863 confirmed cases and 1.141.567 deaths were reported worldwide. 357.693 confirmed cases and 9.658 deaths were reported in Turkey (World Health Organization, 2020).

There are many studies on the negative psychological effects of the pandemic in many countries that were affected by the it (Cao et al., 2020; Chen et al., 2020; Chew et al., 2020; Lopes \& Jaspal, 2020; Meng et al., 2020; Shevlin et al., 2020; Soraci et al., 2020; Tan et al., 2020; Wang, Horby, et al., 2020; Wang, Pan, et al., 2020; Yang et al., 2020; Zhang et al., 2020). Studies showed that pandemic causes anxiety (Asmundson \& Taylor, 2020; Jungmann \& Witthöft, 2020; Li et al., 2020; Moghanibashi-Mansourieh, 2020; Nemati et al., 2020; Roy et al., 2020; Shanafelt et al., 2020; Talidong \& Toquero, 2020); anxiety and depression (Huang \& Zhao, 2020; Ozamiz-Etxebarria et al.2020; Özdin \& Bayrak Özdin, 2020; Pappa et al., 2020) and fear in individuals (Ahorsu, et al., 2020; Doshi et al., 2020; Guan et al. ., 2020; Haktanir et al., 2020; Huang et al., 2020; Ornell, et al., 2020; Pakpour \& Griffiths, 2020; Satici et al., 2020).

In Spain, one of the countries most affected by the pandemic, Ozamiz-Etxebarria et al. (2020) examined adults' level of anxiety, stress, and depression. Although symptom levels were generally low at the onset of the pandemic alert, young individuals with chronic diseases reported more symptoms than the rest of population. The study also reported higher levels of symptoms after an order to stay home. In England, Shevlin et al. (2020) found higher levels of anxiety, depression and trauma symptoms compared to previous population studies. In Turkey, Satici et al. (2020a) reported that fear of COVID-19 increases depression, anxiety and stress, and decreases life satisfaction. In China, Bo et al. (2020) conducted a study on COVID-19 patients. According to the findings of this study, it was found that most of the patients had significant post-traumatic stress symptoms before discharge from hospital.

Transmission of the COVID-19 pandemic, the uncertainty over patient outcomes, practices such as physical and social isolation to protect the health of the public and the news in printed, visual and social media covering the number of COVID-19 infected individuals and deaths induced fear in many people around the world. (Guan et al., 2020; Huang et al., 2020; Pakpour \& Griffiths, 2020). The literature on the virus outbreaks in history has highlighted the negative psychosocial consequences of fear in terms of increasing the harm of an infectious disease (eg, Pappas et al., 2009).

Fear is an unpleasant mood that is triggered by the perception of a threatening stimuli. It is represented by facing with immediate, concrete and overwhelming physical danger (Smith et al., 2014). Fear is a widely researched psychological construct, 
and dozens of psychometric 'fear scales' that assess individuals' level of fear of many different things have been developed (Pakpour \& Griffiths, 2020).

To understand the psychological implications of a pandemic, emotions such as fear and anger need to be considered and observed. In other words, it is important to evaluate fears. It will not be known whether education and prevention programs are necessary and which groups these programs will target (Pakpour \& Griffiths, 2020) without having knowledge about the levels of fear based on different socio-demographic variables (e.g., gender, age, education, religiosity, etc.). Therefore, Ahorsu et al. (2020) developed the COVID-19 Fear Scale to help assess the level of public fear during COVID-19. Satici et al. (2020a) adapted this scale to Turkish. In this context, Üsküdar University Epidemiological Research Group (2020) researched in which ways the fears, anxieties and perceptions of process management of the community affected the psychological maturity level of the community in Turkey that was affected by this outbreak. As a result, it was found that $49 \%$ of women and $35 \%$ of men were afraid of the coronavirus in a way that would affect their lives. Despite these fears and concerns, it was found that the majority of the participants reported psychological maturation. Satici et al. (2020b) examined the relationship between intolerance to uncertainty and mental well-being; and the mediating role of the fear of COVID-19, and rumination in this relationship. Results showed that intolerance to uncertainty has a significant and direct effect on mental well-being. It was revealed that the fear of COVID-19 and rumination together turned out to have a serial mediating effect on the relationship between intolerance to uncertainty and mental well-being.

It can be said that the COVID-19 pandemic caused some kind of mental trauma in humans. In traumatic situations, some individuals seek a new sense of meaning and purpose in their lives, while others think that life is empty and meaningless due to stress, existential uncertainty, and endurance (Smith, 2004; Tedeschi \& Calhoun, 1995). In such times, spiritual well-being and spiritual practices are seen as important components in almost all cultures. Spiritual well-being helps individuals to cope with stressful life events (Bekelman et al., 2009; Dalmida et al. 2011; Jahani et al., 2014; McNulty, Livneh, \& Wilson, 2004; Uğurluoğlu \& Erdem, 2019). Spiritual well-being is defined as a continuous and dynamic reflection on the individual's spiritual health and maturity; emphazises two dimensions: religious and existential (Ellison, 1983). Religious well-being refers to the relationship with a supreme power / God, and existential well-being is interpreted as trying to understand the meaning and purpose of life (Ellison, 2006). Studies have found that spiritual well-being is negatively associated with fear of death (Chung et al., 2015), and positively associated with health-related quality of life (Dalmida et al., 2011). Uğurluoğlu and Erdem (2019) found that the level of spiritual well-being has a positive effect on the post-traumatic growth of individuals. Spirituality includes the elements of hope, meaning of life, prayer, unity 
and connection with nature, belief in the existence of a supreme power, and transcendence (Dein, 2013; Moreira-Almeida \& Koenig, 2006; Myers et al., 2000).

Shaw et al. (2005) reviewed 11 studies investigating the relationship between posttraumatic growth and religion/spirituality. As a result, three main findings have been detected. First, religion and spirituality are generally beneficial to people after trauma; second, traumatic experiences can lead to deepening of spirituality; third, it was concluded that positive religious coping, religious openness, religious participation, inner piety, and readiness to face existential questions are associated with post-traumatic growth.

Kluge, WHO Regional Director for Europe, stated that how we manage and react to this stressful situation that occurs so rapidly in our lives in such a pandemic environment is a big problem we face (Kluge, 2020). Therefore, studying the fear of COVID-19, one of the psychological effects of the pandemic, and spiritual well-being as a coping strategy together in times of trauma are thought to be important in explaining how people cope with a such trauma.

In this study, it is aimed to examine the fear of COVID-19 in terms of spiritual well-being and various socio-demographic variables. As mentioned above, in order to understand the psychological reflections of a pandemic, it is important to evaluate the fear according to different demographic variables (e.g., gender, age, education, occupation, marital status, religiosity, etc.). Thus, research data is needed to develop evidence-based strategies. In this way, it can be predicted which psychosocial and prevention programs will be required and which groups these programs will target.

\section{Method}

\section{Research Model}

In this study, correlational survey model was used to reveal the relationships between fear of COVID-19 and spiritual well-being as well as fear of COVID-19 and some demographic variables (e.g., gender, age, education, occupation, marital status, relatives diagnosed with COVID-19) (Büyüköztürk et al., 2010)

\section{Study Group}

The study group of the research consisted of 474 participants who are convenient and accessible (Gravetter \& Forzano, 2012). The data were collected using the Google Forms service via social media. The data was collected between $21^{\text {st }}$ and $30^{\text {th July, }}$ 2020. Participants' written informed consent was taken before data collection. The general characteristics of the participants are presented in Table 1. 
Table 1.

General Characteristics of Participants $(N=474)$

\begin{tabular}{lll}
\hline Characteristics & Category & $\mathrm{n}(\%)$ \\
\hline \multirow{2}{*}{ Gender } & Female & $261(55.1)$ \\
& Male & $213(44.9)$ \\
\hline \multirow{2}{*}{ Age range } & $18-25$ & $84(17.7)$ \\
& $26-40$ & $248(52.3)$ \\
& $41-55$ & $123(25.9)$ \\
& Above 55 years of age & $19(4.0)$ \\
\hline \multirow{2}{*}{ Education } & Primery school ${ }^{\mathrm{a}}$ & $57(12.0)$ \\
& High school & $66(13.9)$ \\
& Undergraduate & $279(58.9)$ \\
& Postgraduate & $72(15.2)$ \\
\hline \multirow{3}{*}{ Profession } & Officer & $183(38.6)$ \\
& Employee & $53(11.2)$ \\
& Craft & $51(10.8)$ \\
& Student & $57(12.0)$ \\
Economical situation & Other (unemployed and housewife) & $130(27.4)$ \\
& Low & $37(7.8)$ \\
\hline \multirow{2}{*}{ Marital status } & Middle & $414(87.3)$ \\
\hline \multirow{2}{*}{ A relative diagnosed with COVID-19 } & High & $23(4.9)$ \\
\hline
\end{tabular}

According to Table 1, study group consists of 261 (55.1\%) female and 213 (44.9\%) male participants. Eighty-four (17.7\%) participants from the study group are between the ages of 18-25, 248 (52.3\%) are between the ages of 26-40, 123 (25.9\%) are 41-55, and 19 (4\%) were 56-years and over. In terms of the level of education, 57 (12\%) participants are primary education graduates, 66 (13.9\%) are high school graduates, 279 $(58.9 \%)$ have a bachelor's degree and $72(15.2 \%)$ have postgraduate degree. In terms of the professions they have, 183 (38.6\%) participants are officer, 53 (11.2\%) are employee, $51(10.8 \%)$ are tradesmen, $57(12.0 \%)$ are students, and $130(27.4 \%)$ marked the other option (unemployed, housewives, etc.). In terms of economic status, 37 (7.8\%) people reported low income, 414 (87.3\%) reported middle income, 23 (4.9\%) reported high income. In terms of marital status, $319(67.3 \%)$ of the participants are married and 155 (32.7\%) are single. The number of people reporting that they have an acquaintance who was diagnosed with COVID-19 was 76 (16\%), 398 (84.0\%) reported that they do not have an acquaintance who was diagnosed with COVID-19.

\section{Acknowledgment}

Ethics approval was obtained from the Scientific Research and Publication Ethics Board of Istanbul 29 Mayıs University to conduct the study (Decision No: 2020 / 02-01). 


\section{Data Collection Tools}

Demographic Information Form. It is a form prepared by the researcher consisting of a number of questions such as age, gender, marital status, education, profession, income level of the individuals, and whether there is a person diagnosed with COVID-19 among their acquaintances.

COVID-19 Fear Scale. The COVID-19 Fear Scale (K19-FS) is a one-dimensional scale which was developed by Ahorsu et al (2020). The scale consists of 7 items (Some items of the scale: "I am very afraid of the coronavirus"; "Thinking about the coronavirus disturbs me"; "When I watch the news and stories about the coronavirus on social media, I feel anxious"). The scale is a 5-point Likert type scale ( 1 = strongly disagree, 5 $=$ totally agree). Factor loads (.66-.74) and corrected item-total correlation (.47-.56) of the scale were found to be acceptable. The internal consistency of the scale was calculated as $\alpha=.82$ and test-retest reliability as $r=.72$. K19-FS showed a positive correlation with perceived weakness, hospital anxiety, and depression (Ahorsu et al., 2020).

K19-FS has been adapted into Turkish by Satici et al (2020). Confirmatory factor analyzes of the scale showed that all fit indices were within acceptable limits $[\chi 2$ $(13, \mathrm{~N}=1304)=299.47, \mathrm{SRMR}=.061, \mathrm{GFI}=.936, \mathrm{NFI}=.912, \mathrm{IFI}=.915, \mathrm{CFI}$ $=.915]$. According to the Item Response Theory, the analysis results (all $\alpha$ values higher than 1.0) revealed that the scale has appropriate item difficulty and the ability to distinguish between performers and nonperformers. Concurrent validity was evaluated by calculating the correlations of K19-FS with depression, anxiety, stress and life satisfaction. Analyzes showed a significant positive correlation between K19-FS and depression $(\mathrm{r}=.38, p<.001)$, anxiety $(\mathrm{r}=.55, p<.001)$ and stress $(\mathrm{r}=.47, p$ $<.001)$; revealed a significant and negative correlation $(\mathrm{r}=-.20, p<.001)$ with life satisfaction. In this study, the internal consistency coefficient of the scale is $\alpha=.91$.

Three-Factor Spiritual Well-Being Scale. The Three-Factor Spiritual Well-Being Scale (3F-SWBS) was developed by Ekşi and Kardaş (2017) for adults. The scale is a 5 -point Likert type scale $(1=$ not suitable at all, $5=$ completely appropriate $)$ and has 29 items. The scale has a 3-factor structure: Transcendence, Harmony with Nature and Anomie. As a result of the confirmatory factor analysis, an acceptable model emerged $\left(\chi^{2}\right.$ $/ \mathrm{df}=4.11, \mathrm{RMSEA}=.06, \mathrm{SRMR}=.50, \mathrm{NFI}=.90, \mathrm{CFI}=.92)$. The internal consistency values of the sub-dimensions of the scale are $\alpha=.95$ for Transcendence, $\alpha=.86$ for Harmony with Nature, and $\alpha=.85$ for Anomie; for the total of the scale, $\alpha=.89$. To calculate the total scale score, items in the Anomie sub-dimension should be reverse-scored. In this study, the internal consistency coefficient calculated for the total scale is $\alpha=.73 ; \alpha=.86$ for Transcendence, $\alpha=.66$ for Harmony with Nature, and $\alpha=.85$ for Anomie. 


\section{Analysis of Data}

Before starting data analysis, missing and incorrectly filled forms $(n=10)$ were excluded. Outliers were calculated with the Malahanobis distance and 39 data were excluded from the analysis. The analyzes were conducted with 474 data. Univariate and multivariate normality were calculated with skewness and kurtosis coefficients; the reliability of K19-FS and 3F-SWBS was examined with the Cronbach alpha coefficient. Data was tested with descriptive statistics, Pearson Correlation Coefficient, t test for independent groups, one-way ANOVA and multiple regression analysis. When interpreting the findings obtained as a result of the analyzes, $p<.05$ significance level was taken as a basis and the analyzes were made with the SPSS program.

\section{Results}

\section{Descriptive Statistics and Correlation Analysis}

The associations among the study variables were examined using the Pearson product-moment correlation coefficient. Descriptive statistics and correlation values for the variables are shown in Table 2 .

Table 2.

Descriptive and Pearson Correlation Analyzes

\begin{tabular}{|c|c|c|c|c|c|}
\hline & $\begin{array}{c}\text { Fear of } \\
\text { COVID-19 }\end{array}$ & $\begin{array}{c}\text { SWB- } \\
\text { Transcendence }\end{array}$ & $\begin{array}{c}\text { SWB- } \\
\text { Harmony with } \\
\text { Nature }\end{array}$ & SWB-Anomie & $\begin{array}{l}\text { Total Spiritual } \\
\text { Well-being }\end{array}$ \\
\hline Fear of COVID-19 & & $-.10 *$ & -.05 & $.32 * *$ & $-.25 * *$ \\
\hline SWB-Transcendence & & & $.51 * *$ & $-.25 * *$ & $.79 * *$ \\
\hline $\begin{array}{l}\text { SWB-Harmony with } \\
\text { Nature }\end{array}$ & & & & $-.24 * *$ & $.65 * *$ \\
\hline SWB-Anomie & & & & & $-.76^{* *}$ \\
\hline Mean (SD) & $17.72(7.05)$ & $69.39(5.95)$ & $32.06(2.96)$ & $16.49(6.55)$ & $126.97(11.57)$ \\
\hline Skewness & .44 & -1.36 & -1.03 & .76 & -.62 \\
\hline Kurtosis & -.58 & 1.37 & .45 & -.01 & -.26 \\
\hline
\end{tabular}

In Table 2, the skewness values of the scores are between -1.36 and .44 , and the kurtosis values are between -.58 and 1.37. Accordingly, the data showed a normal distribution (-2.00 to 2.00) (George \& Mallery, 2019). According to the results of correlation analysis, negative correlation between fear of COVID-19 and spiritual wellbeing, and the subscale of spiritual well-being "transcendence" $(\mathrm{r}=-.25, p<0.01 ; \mathrm{r}$ $=-.10, p<0.05$ ) was found; and a positive correlation between the fear of COVID-19 and the subscale of spiritual well-being "anomie" $(\mathrm{r}=.32, p<0.01)$ was found. 


\section{Spiritual Well-being Predicts Fear of COVID-19}

Multiple regression analysis was conducted to determine whether the subscale of spiritual well-being (transcendence, harmony with nature, and anomie) predicts the fear of COVID-19. The results are presented in Table 3.

Table 3.

Prediction of Fear of COVID-19

\begin{tabular}{lccccccc}
\hline Variable & $\mathrm{B}$ & $\mathrm{SE}$ & $\beta$ & $\mathrm{t}$ & $p$ & Zero-order r & Partial r \\
\hline Constant & 12.253 & 4.474 & - & 2.239 & .006 & - & - \\
Anomie & .343 & .049 & .319 & 7.008 & .000 & .319 & .308 \\
Transcendence & -.059 & .061 & -.050 & -.973 & .331 & -.104 & -.045 \\
Harmony with nature & .122 & .122 & .051 & .999 & .318 & -.052 & .046 \\
$\mathrm{R}=.323$ & & $\mathrm{R}^{2}=.104$ & & & & & \\
$\mathrm{~F}_{(3-470)}=18.247$ & & $p=.000$ & & & & & \\
\hline
\end{tabular}

SE: Standard Error.

According to Table 3, the variables of anomie, transcendence and harmony with nature, which are the sub-scales of spiritual well-being, showed a significant relationship with the fear of COVID-19 $\left(\mathrm{R}=.323, \mathrm{R}^{2}=.104 ; \mathrm{F}_{(3-470)}=18.247, p<.001\right)$. These three variables together explain $10 \%$ of the variance in the fear of COVID-19. According to the significance tests of the regression coefficients, anomie $(p<.001)$ is a significant predictor of fear of COVID-19. The results show that the anomie positively predicts the fear of COVID-19.

\section{Fear of COVID-19 Based on Demographic Characteristics of the Participants}

The level of fear of COVID-19 was examined based on gender, age range, education, occupation, income level, marital status, and the status of an acquiantance who was diagnosed with COVID-19. For this, the mean and standard deviation of the variables were calculated; $t$ test and one-way ANOVA analyzes were performed for independent groups. Analysis results are presented in Table 4.

According to Table 4, the mean scores of the participants of fear of COVID-19 vary significantly according to gender $(\mathrm{t}=4.04, p<.001)$ and education $(\mathrm{F}=6.53$, $p<.001)$. Accordingly, the average score of women $\left(\overline{\mathrm{X}}_{\text {female }}=18.89\right)$ is higher than the average score of men $\left(\overline{\mathrm{X}}_{\text {male }}=16.30\right)$. According to their educational status, the average score of those with postgraduate education $\left(\bar{X}_{\text {postgraduate }}=15.08\right)$ is lower than the average score of undergraduate, high school and primary school graduates $(\overline{\mathrm{X}}=$ $17.64_{\text {undergraduate }}, \overline{\mathrm{X}}_{\text {high school }}=18.75, \overline{\mathrm{X}}_{\text {primary school }}=20.26$ ). In Table 3, it is seen that the fear of COVID-19 does not differ according to age range, profession, income level, marital status, and COVID-19 diagnosis status of the acquaintance. 
Table 4.

Fear of COVID-19 According to the General Characteristics of the Participants

\begin{tabular}{|c|c|c|c|}
\hline Characteristics & Category & $\overline{\mathrm{X}}(\mathrm{SD})$ & $t / \mathrm{F}$ \\
\hline \multirow{2}{*}{ Gender } & Female & $18.89(7.02)$ & \multirow{2}{*}{$4.04 *$} \\
\hline & Male & $16.30(6.83)$ & \\
\hline \multirow{4}{*}{ Age range } & $18-25$ & $16.34(6.13)$ & \multirow{4}{*}{2.18} \\
\hline & $26-40$ & $17.69(7.22)$ & \\
\hline & $41-55$ & $18.8(7.3)$ & \\
\hline & Above 55 years of age & $17.0(7.05)$ & \\
\hline \multirow{4}{*}{ Education } & Primery school $^{\mathrm{a}}$ & $20.26(8.06)$ & \multirow{4}{*}{$\begin{array}{l}6.53 * \\
b<a\end{array}$} \\
\hline & High school $^{\mathrm{a}}$ & $18.75(6.87)$ & \\
\hline & Undergraduate $^{\mathrm{a}}$ & $17.64(6.79)$ & \\
\hline & Postgraduate $^{\mathrm{b}}$ & $15.08(6.54)$ & \\
\hline \multirow{5}{*}{ Profession } & Officer & $18.08(7.27)$ & \multirow{5}{*}{2.18} \\
\hline & Employee & $19.62(7.49)$ & \\
\hline & Craft & $18.0(6.93)$ & \\
\hline & Student & $16.1(6.14)$ & \\
\hline & Other (unemployed and housewife) & $17.03(6.83)$ & \\
\hline Economical situation & & & $18.89(6.70)$ \\
\hline Low & & & $17.78(7.04)$ \\
\hline Middle & & & $14.65(7.05)$ \\
\hline High & & & 2.73 \\
\hline \multirow{2}{*}{ Marital status } & Married & $18.13(7.14)$ & \multirow{2}{*}{1.82} \\
\hline & Single & $16.87(6.81)$ & \\
\hline \multirow{2}{*}{ A relative diagnosed with COVID-19 } & Yes & $17.77(7.28)$ & \multirow{2}{*}{.07} \\
\hline & No & $17.71(7.01)$ & \\
\hline
\end{tabular}

$* p<0.001$.

\section{Discussion}

In this study, the relationship between fear of COVID-19 and spiritual wellbeing was investigated. At the same time, the fear of COVID-19 was examined according to the gender, age range, education, occupation, income level, marital status, and diagnosis status of the acquaintance. The findings are discussed below.

The first result of the research is that the fear of COVID-19 is negatively related with transcendence, which is one of the sub-dimensions of total spiritual well-being., and positively correlated with anomie. In other words, as the total spiritual well-being and transcendence increase, the fear of COVID-19 decreases; the higher the anomie is the higher the fear of COVID-19 gets. In addition, the high level of anomie is a predictive factor in the increase of COVID-19 fear. There is no study in the literature that can be directly compared with these findings. However, in a study examining the relationship between spiritual well-being and fear of death, a negative relationship was found between them. Accordingly, the higher the level of spiritual well-being is the lower the level of stress or anxiety about death gets (Chung et al., 2015). In another study, it was found that spiritual well-being has a positive effect on post-traumatic growth of individuals who have experienced trauma (Uğurluoğlu \& Erdem, 2019). 
In this research, spiritual well-being was evaluated in three dimensions. Among these dimensions, "transcendence" includes elements such as attachment to a Higher power, sheltering in His power, strength of belief to endure difficulties, contemplation and consolation; "harmony with nature" includes elements such as respect for nature and living creatures, and integration with nature; "anomie" includes elements such as existential emptiness, discontent, lack of meaning and purpose (Ekşi \& Kardaş, 2017). Based on these points, it can be said that individuals who are more connected with a supreme power, in realization of its power and take shelter in it; give life a meaning and purpose, have low levels of fear of coronavirus. As a matter of a fact, it was found that the high anomie increased the level of fear of coronavirus.

When individuals' level of spiritual well-being is high, they can react positively to stress and distress, and their level of fear may decrease. Studies in the literature show that spirituality has a significant negative relationship with anxiety (Glas \& Poort, 2007; Nelson et al., 2009; Reutter \& Bigatti, 2014). In this traumatic period created by COVID-19, spirituality can be a source for people to develop a new sense of meaning and purpose in their lives; they can keep their hopes alive, and try to make sense of their problems by connecting with the sacred. At the same time, individuals can protect their psychological health, and deal with stress and stressful conditions in a positive way. Shaw et al. (2005) reviewed some studies in the literature and concluded that spiritual values generally increase and deepen after trauma and are beneficial to people. They make them ready to face existential questions and contribute to post-traumatic growth.

According to another finding of the study, women had higher levels of fear of COVID-19 than men. This finding shows parallels with the results of the similar studies conducted during this period (Doshi et al., 2020; Haktanir et al., 2020). On the other hand, Ahorsu et al. (2020) did not find a difference between genders in their studies. Considering that women are affected by fear or phobia twice as often as men (American Psychiatric Association, 2013), the finding of this study is a reasonable result.

In this study, fear of COVID-19 was also examined based on education level. As a result, it was found that individuals with a postgraduate degree have lower levels of fear of COVID-19 than the others (undergraduate, high school, primary education graduates). This finding shows parallels with the findings of Doshi et al. (2020). On the other hand Haktanir et al. (2020) did not find a significant difference between individuals from different education levels in terms of the fear of COVID-19. The different results of the studies show that the relationship between education level and the fear of COVID-19 should be studied further. However, based on the results of this research, it can be said that the level of education significantly affects the individual's understanding of pandemic, infection and prevention of the infection. 
It was also found that there is no significant difference between the fear of $\mathrm{CO}$ VID-19 and age range, profession, income level, the infection status of relatives and marital status. Analyses revealed that individuals of different age ranges, occupation, income level, marital status, and those with or without an acquitance diagnosed with COVID-19 report similar levels of fear. Similarly, in the study of Haktanir et al. (2020) no significant difference was found by age range. Doshi et al. (2020) found that individuals between the ages of 20-40 experience more fear.

These research findings have some limitations. First, the data was collected from the sample that showed no clinical symptoms. Therefore, it is recommended that the findings are not to be generalized to clinical cases. Second, it has been difficult to reach some subgroups. Since access to older adults via online form was low, representation of this subgroup in this sample was limited. It is reccommended to investigate this phenomenon with subgroups that are more represented more equally. Third, the findings are based on a data obtained from self-report scales. This situation carries the risk of bias.

COVID-19 creates many uncertainties in the lives of individuals and when these uncertain situations are perceived as threatening, they can lead to stress and fear by causing negative reactions in the person. Spiritual well-being can provide a way of dealing with stress and fear. In times of such trauma, individuals will be able to cope with fear as long as they are spiritually well and able to use their spiritual resources. From this point of view, practices for spiritual well-being (eg, mindfulness, logotherapy, etc.) during this period can help individuals to improve their ability to cope with the fear and trauma created by this pandemic, thereby reducing their fear and anxiety levels. In addition, in terms of developing evidence-based strategies, it seems important to consider the research findings in psycho-social intervention studies that women and individuals with lower education levels experience more fear of COVID-19, to prevent the negative psychological effects that may be caused by that fear.

\section{References}

Ahorsu, D. K., Lin, C., Imani, V., Saffari, M., Griffiths, M. D., \& Pakpour, A. H. (2020). The fear of COVID-19 scale: Development and initial validation. InternationalvJournal of Mental Health and Addiction. https://doi.org/10.1007/s11469-020-00270-8

Asmundson, G. J., \& Taylor, S. (2020). How health anxiety influences responses to viral outbreaks like COVID-19: What all decision-makers, health authorities, and health care professionals need to know. Journal of Anxiety Disorders, 71, 102211. https://dx.doi.org/10.1016\%2Fj.janxdis.2020.102211,

Bekelman, D.B., Rumsfeld, J.S., \& Havranek, E.P. (2009). Symptom burden, depression, and spiritual well-being: A comparison of heart failure and advanced cancer patients. Journal of General Internal Medicine 24(5), 592-598.

Bo, H., Li, W., Yang, Y., Wang, Y., Zhang, Q., Cheung, T., Wu, X., \& Xiang, Y. (2020). Posttraumatic stress symptoms and attitude toward crisis mental health services among clinically stable patients with COVID-19 in China. Psychological Medicine as part of the Cambridge Coronavirus Collection. https://doi.org/10.1017/S0033291720000999 
Büyüköztürk, Ş., Çakmak, E.K., Akgün, Ö.E., Karadeniz, Ş., \& Demirel F. (2010). Bilimsel araştırma yöntemleri (5. baskı). Pegem Akademi.

Cao, W., Fang, Z., Hou, G., Han, M., Xu, X., Dong, J., \& Zheng, J. (2020). The psychological impact of the COVID-19 epidemic on college students in China. Psychiatry Research, 112934. doi: https://doi. org/10.1016/j.psychres.2020.112934

Chen, P., Mao, L., Nassis, G. P., Harmer, P., Ainsworth, B. E., \& Li, F. (2020). Wuhan coronavirus (2019$\mathrm{nCoV})$ : The need to maintain regular physical activity while taking precautions. Journal of sport and health science, 9(2), 103. https://dx.doi.org/10.1016\%2Fj.jshs.2020.02.001

Chew, N. W., Lee, G. K., Tan, B. Y., Jing, M., Goh, Y., Ngiam, N. J., ... \& Sharma, A. K. (2020). A multinational, multicentre study on the psychological outcomes and associated physical symptoms amongst healthcare workers during COVID-19 outbreak. Brain, behavior, and immunity. https://doi. org/10.1016/j.bbi.2020.04.049

Chung, M. Y., Cha, K. S., \& Cho, O. H. (2015). Correlation between self-esteem, death anxiety, and spiritual wellbeing in Korean university students. Korean Journal of Adult Nursing, 27(3), 367-374. http://dx.doi.org/10.7475/kjan.2015.27.3.367

Dalmida, S. G., Holstad, M. M., Dilorio, C., \& Laderman, G. (2011). Spiritual well-being and healthrelated quality of life among African-American women with HIV/AIDS. Applied research in quality of life, 6(2), 139-157. Doi:10.1007/s11482-010-9122-6

Dein, S. (2013). Religion, spirituality, depression, and anxiety: Theory, research, and practice. In K. I. Pargament (Ed.). APA handbook of psychology, religion and spirituality: Vol. 2. An applied psychology of religion and spirituality (pp. 241-255). Washington DC: American Psychological Association.

Doshi, D., Karunakar, P., Sukhabogi, J. R., Prasanna, J. S., \& Mahajan, S. V. (2020). Assessing Coronavirus Fear in Indian Population Using the Fear of COVID-19 Scale. International Journal of Mental Health and Addiction, 1. https://doi.org/10.1007/s11469-020-00332-x

Ellison, L. (2006). A review of The Spiritual Well-Being Scale. NewsNotes, 44(1).

Ellison, C. W. (1983). Spiritual well-being: conceptualization and measurement. Journal of Psychology and Theology, 11(4), 330-340.

Glas, G., \& Poort, Z. (2007). Anxiety, anxiety disorders, religion and spirituality. Southern medical journal, 100(6), 621-625.

Gravetter, J. F., \& Forzano, L. B. (2012). Research methods for the behavioral sciences (4th ed.). Wadsworth, Cengage Learning.

Guan, W., Ni, Z., Hu, Y., Liang, W., Ou, C., ... \& Zhong, N. (2020). Clinical characteristics of coronavirus disease 2019 in China. New England Journal of Medicine. Epub ahead of print. https://doi. org/10.1056/nejmoa2002032.

Haktanir, A., Seki, T., \& Dilmaç, B. (2020). Adaptation and evaluation of Turkish version of the fear of COVID-19 scale. Death Studies, 1-9. https://doi.org/10.1080/07481187.2020.1773026

Huang, Y., \& Zhao, N. (2020). Generalized anxiety disorder, depressive symptoms and sleep quality during COVID-19 epidemic in China: A web-based cross-sectional survey. medRxiv. https://doi.org/ 10.1101/2020.02.19.20025395.

Jahani, A., Rejeh, N., Heravi-Karimooi, M., Vaismoradi, M., \& Jasper, M. (2014). Spiritual wellbeing of Iranian patients with acute coronary syndromes: a cross-sectional descriptive study. Journal of Research in Nursing, 19(6), 518-527. https://doi.org/10.1177\%2F1744987114547606

Jungmann, S. M., \& Witthöft, M. (2020). Health anxiety, cyberchondria, and coping in the current COVID-19 pandemic: Which factors are related to coronavirus anxiety? Journal of Anxiety Disorders, 102239. https://doi.org/10.1016/j.janxdis.2020.102239

Kluge, H. H. P. (2020). Mental health and psychological resilience during the COVID-19 pandemic. http://www.euro.who.int/en/health-topics/health-emergencies/coronavirus-covid- 
Li, S. W., Wang, Y., Yang, Y. Y., Lei, X. M., \& Yang, Y. F. (2020). Analysis of influencing factors of anxiety and emotional disorders in children and adolescents during home isolation during the epidemic of novel coronavirus pneumonia. Chinese Journal of Child Health, 28(3), 1-9.

Lopes, B. C. d. S., \& Jaspal, R. (2020). Understanding the mental health burden of COVID-19 in the United Kingdom. Psychological Trauma: Theory, Research, Practice, and Policy, 12(5), 465-467. http://dx.doi.org/10.1037/tra0000632

McNulty, K., Livneh, H., \& Wilson, L. M. (2004). Perceived uncertainty, spiritual well-being, and psychosocial adaptation in individuals with multiple sclerosis. Rehabilitation Psychology, 49(2), 9199. https://psycnet.apa.org/doi/10.1037/0090-5550.49.2.91

Meng, H., Xu, Y., Dai, J., Zhang, Y., Liu, B., \& Yang, H. (2020). The psychological effect of COVID-19 on the elderly in China. Psychiatry Research, 112983. https://doi.org/10.1016/j.psychres.2020.112983

Moghanibashi-Mansourieh, A. (2020). Assessing the anxiety level of Iranian general population during COVID-19 outbreak. Asian journal of psychiatry, 102076. https://doi.org/10.1016/j.ajp.2020.102076

Moreira-Almeida, A., \& Koenig, H. G. (2006). Retaining the meaning of the words religiousness and spirituality. Social Science \& Medicine, 63(4), 840-845. https://doi.org/10.1016/j.socscimed.2006.03.001

Myers, J. E., Sweeney, T. J., \& Witmer, J. M. (2000). The wheel of wellness counseling for wellness: A holistic model for treatment planning. Journal of Counseling and Development, 78(3), 251-266. doi: org/10.1002/j.1556-6676.2000.tb01906.x

Nemati, M., Ebrahimi, B., \& Nemati, F. (2020). Assessment of Iranian nurses' knowledge and anxiety toward COVID-19 during the current outbreak in Iran. Archives of Clinical Infectious Diseases, 15(COVID-19). http://dx.doi.org/10.5812/archcid.102848

Nelson, C., Jacobson, C. M., Weinberger, M. I., Bhaskaran, V., Rosenfeld, B., Breitbart, W., \& Roth, A. J. (2009). The role of spirituality in the relationship between religiosity and depression in prostate cancer patients. Annals of Behavioral Medicine, 38(2), 105-114.

Ornell, F., Schuch, J. B., Sordi, A. O., \& Kessler, F. H. P. (2020). "Pandemic fear" and COVID-19: mental health burden and strategies. Brazilian Journal of Psychiatry, 42(3), 232-235. https://doi. org/10.1590/1516-4446-2020-0008

Ozamiz-Etxebarria, N., Dosil-Santamaria, M., Picaza-Gorrochategui, M., \& Idoiaga-Mondragon, N. (2020). Stress, anxiety, and depression levels in the initial stage of the COVID-19 outbreak in a population sample in the northern Spain. Cadernos de Saúde Pública, 36, e00054020. https://doi. org/10.1590/0102-311X00054020

Özdin, S., \& Bayrak Özdin, Ş. (2020). Levels and predictors of anxiety, depression and health anxiety during COVID-19 pandemic in Turkish society: The importance of gender. International Journal of Social Psychiatry, 0020764020927051. https://doi.org/10.1177\%2F0020764020927051

Pakpour, A. H., \& Griffiths, M. D. (2020). The fear of COVID-19 and its role in preventive behaviors. Journal of Concurrent Disorders. https://concurrentdisorders.ca/2020/04/03/the-fear-of-covid-19and-its-role-in-preventive-behaviors/

Pappa, S., Ntella, V., Giannakas, T., Giannakoulis, V. G., Papoutsi, E., \& Katsaounou, P. (2020). Prevalence of depression, anxiety, and insomnia among healthcare workers during the COVID-19 pandemic: A systematic review and meta-analysis. Brain, behavior, and immunity. https://doi.org/10.1016/j. bbi.2020.05.026

Pappas, G., Kiriaze, I. J., Giannakis, P., \& Falagas, M. E. (2009). Psychosocial consequences of infectious diseases. Clinical Microbiology and Infection, 15(8), 743-747. https://doi.org/10.1111/j.14690691.2009.02947.x

Reardon, S. (2015). Ebola's mental-health wounds linger in Africa: health-care workers struggle to help people who have been traumatized by the epidemic. Nature, 519(7541), 13-15. 
Reutter, K. K., \& Bigatti, S. M. (2014). Religiosity and spirituality as resiliency resources: Moderation, mediation, or moderated mediation?. Journal for the scientific study of religion, 53(1), 56-72.

Roy, D., Tripathy, S., Kar, S. K., Sharma, N., Verma, S. K., \& Kaushal, V. (2020). Study of knowledge, attitude, anxiety \& perceived mental healthcare need in Indian population during COVID-19 pandemic. Asian Journal of Psychiatry, 102083. https://doi.org/10.1016/j.ajp.2020.102083

Satici, B., Gocet-Tekin, E., Deniz, M. E., \& Satici, S. A. (2020a). Adaptation of the Fear of COVID-19 Scale: Its association with psychological distress and life satisfaction in Turkey. International Journal of Mental Health and Addiction, 1. https://doi.org/10.1007/s11469-020-00294-0

Satici, B., Saricali, M., Satici, S. A., \& Griffiths, M. D. (2020b). Intolerance of uncertainty and mental wellbeing: serial mediation by rumination and fear of COVID-19. International Journal of Mental Health and Addiction. https://doi.org/10.1007/s11469-020-00305-0

Shanafelt, T., Ripp, J., \& Trockel, M. (2020). Understanding and addressing sources of anxiety among health care professionals during the COVID-19 pandemic. Jama, 323(21), 2133-2134. doi:10.1001/ jama.2020.5893

Shaw, A., Joseph, S., \& Linley, P. A. (2005). Religion, spirituality, and posttraumatic growth: A systematic review. Mental Health, Religion \& Culture, 8(1), 1-11. https://doi.org/10.1080/1367467032000157981

Smith, E. E., Nolen-Hoeksema, S., Fredrickson, \& Maren, S. (2014). Psikolojiye giriş (çev., Öznur Öncül ve Deniz Ferhatoğlu, 2. baskı). Arkadaş Yayınevi.

Smith, S. (2004). Exploring the interaction of trauma and spirituality. Traumatology, 10(4), 231-243.

Talidong, K. J. B., \& Toquero, C. M. D. (2020). Philippine teachers' practices to deal with anxiety amid COVID-19. Journal of Loss and Trauma, 1-7. https://doi.org/10.1080/15325024.2020.1759225

Tan, B. Y., Chew, N. W., Lee, G. K., Jing, M., Goh, Y., Yeo, L. L., ... \& Shanmugam, G. N. (2020). Psychological impact of the COVID-19 pandemic on health care workers in Singapore. Annals of Internal Medicine. https://doi.org/10.7326/M20-1083

Tedeschi, R. G., Park, C. L. \& Calhoun, L. G. (1998). Posttraumatic growth: Conceptual issues. In R. G. Tedeschi, C. L. Park and L. G. Calhoun (Ed.), Posttraumatic growth: positive changes in the aftermath of crisis (pp. 1-22). Routledge.

Türk Psikiyatri Derneği. (t.y.). Travma sonrası stres bozukluğu. Erişim adresi: https://www.psikiyatri.org. $\mathrm{tr} /$ halka-yonelik/28/travma-sonrasi-stres-bozuklugu

Uğurluoğlu, D. \& Erdem, R. (2019). Travma geçiren bireylerin spiritüel iyi oluşlarının travma sonrası büyümeleri üzerine etkisi. Dokuz Eylül Üniversitesi Sosyal Bilimler Enstitüsü Dergisi, 21 (3), 833858. http://dx.doi.org/10.16953/deusosbil.507731

Üsküdar Üniversitesi Epidemiyolojik Araştırmalar Grubu. (2020). Türkiye koronafobi ve salgınla ilişkili duygular çalışması. https://uskudar.edu.tr/tr/icerik/5156/turkiyenin-koronafobi-haritasi-aciklandi

Wang, C., Pan, R., Wan, X., Tan, Y., Xu, L., Ho, C. S., \& Ho, R. C. (2020). Immediate psychological responses and associated factors during the initial stage of the 2019 coronavirus disease (COVID-19) epidemic among the general population in China. International Journal of Environmental Research and Public Health, 17(5), 1729. https://doi.org/10.3390/ijerph17051729

Wang, C., Horby, P. W., Hayden, F. G., \& Gao, G. F. (2020). A novel coronavirus outbreak of global health concern. The Lancet, 395(10223), 470-473. https://doi.org/10.1016/S0140-6736(20)30185-9

World Health Organization. (21.07. 2020). Coronavirüs disease. https://covid19.who.int/

Yang, Y., Li, W., Zhang, Q., Zhang, L., Cheung, T., \& Xiang, Y.T. (2020). Mental health services for older adults in China during the COVID-19 outbreak. The lance. Psychiatry, (20)30079-1. https://doi. org/10.1016/S2215-0366(20)30079-1

Zhang, W. R., Wang, K., Yin, L., Zhao, W. F., Xue, Q., Peng, M., ... \& Chang, H. (2020). Mental health and psychosocial problems of medical health workers during the COVID-19 epidemic in China. Psychotherapy and psychosomatics, 89(4), 242-250. https://doi.org/10.1159/000507639 